乳腺症

\section{1 臨床的診断}

乳腺症は乳腺疾患のなかで最も頻度が高く, 一般に25一-45才に多く30才台に最も多い。ま た，閉経後は急減し60才台以上では極めて少な い。乳腺症の発生平均年令は乳癌発生のそれよ り約 $5-10$ 年若く, これが乳腺症より乳癌が発 生する準備期間であると説く者もいる。

乳腺症の腫瘤は両側あるい性側の乳腺内に 1 個ない乙数個の大小不同の硬結を形成し, 触 診ではじめて存在を知る場合が大部分でめる。 腫瘤は癌注ど硬くなく, 境界不鮮明で平手で触 れるよりは指でつまみ上げるよらにすると明ら かになる。大きさは小豆大から黛卵大に至るま で種々で, 表面は全体として凹凸不整で大小種 々の顆粒状結節が集合して形成した塊のように 触れる。硬度はその組織学的性状に起因するた め, 腺症や線維症に傾く部分では弾性硬, 囊胞 の多い部分は弾性軟として触れる。小さい単発 の緊満状の囊胞は案外かたく触れ線維腺腫と誤 ることもある。

そして、これらの結節のなかに一段と硬度を 增したかたい結節を触れた場合には初期癌を疑 わねばならぬ。

疼痛は必ずしも現われないが，軽度の自発痛 や圧痛のあることも㐫る。屯た, 月経前の乳房 緊張感に伴ら軽度の疼痛を訴えることが多いが この痛みは月経後には消失する。

\footnotetext{
* 順天堂大学助手 (胸部外科)

** / 助手 ( / )

*** " 講師 ( $/ 1)$
}

\begin{tabular}{|c|c|c|c|c|}
\hline 外科学教室 & 石 & 毛 & & 寛* \\
\hline & 堤 & & 正 & 夫** \\
\hline & 八 & 木 & 義 & 弘**** \\
\hline
\end{tabular}

乳頭異常分泌が時にみられるが，大半は囊胞 に関係する乳汁様, 漿液性のもので血性のこと は少ない。血性分泌の場合は乳頭腫症に起因す ることが多いが乳癌との鑑別を要する。乳腺症 の診断方法は, 従来からの触診法が現在なお最 も有力かつ有効な方法であるが，種々な補助的 診断法が開発，利用されるようになった。現在 行なわれている主なものについて述べる。

\section{$<$ 補助的診断法 $>$}

\section{1）超音波診断}

超音波による乳腺症の診断には基本因子とし $\tau$ 1) fine linear pattern 2) fine spotted pattern 3) combined pattern 4) almost homogenous pattern の表現が用いられてい る。乳腺症の超音波像と組織像との相関々係が みられないことから, 反射像の基本型と組織と の関係よりむしろ乳癌との鑑別に重点が置かれ ている。乳癌の超音波反射像の基本因子として は 1) irregular malignant pattern 2) malignant homogenous pattern に大別されて いる。

両者の鑑別点をみると乳腺症の反射像は微細 線状及び微細点状像を示すが, 乳癌の反射像 は, 同一感度に於いても, 乳癌組織の減衰度の 増加から底面ェコーの欠除, 透明領域の輪郭が 不規則で岀るものが多い。

図(1)の如く小さい癌にみられる限局した不規 則な反射の強い像との比較であるが，乳癌では 同一感度でも感度を下げ，周囲乳腺組織の反射 が消失しても尚反射像が残っているが乳腺症で は均一に消失する。 
図 1 Ultrasono-tomograms of Eary Breast Cancer linear scan. Freq. $5 \mathrm{MHz}$

Breast Cancer $2 \times 1 \mathrm{~cm}$

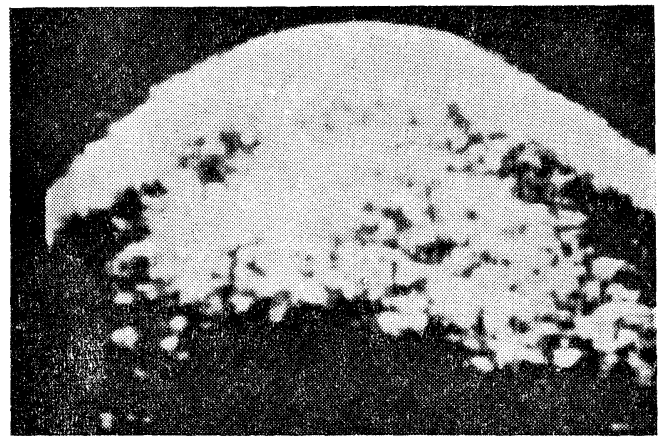

$O \mathrm{~dB}$

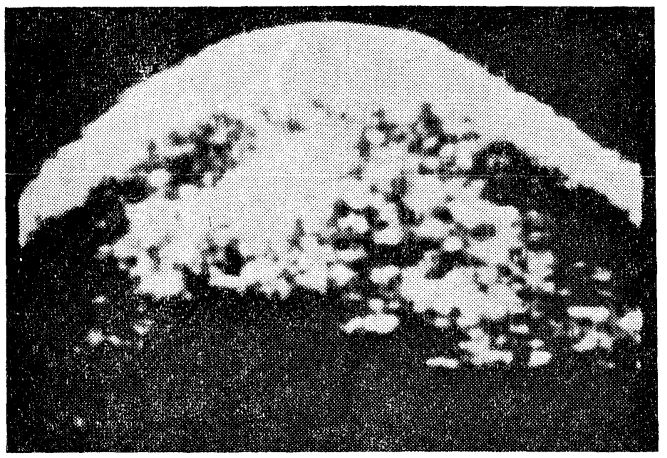

$3 \mathrm{~dB}$

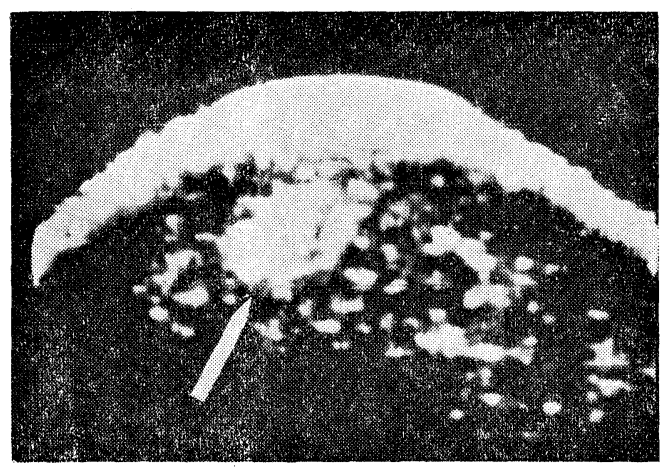

$6 \mathrm{~dB}$

尚乳腺症の経過中に乳癌への移行もあること から年 $2 \sim 3$ 回の定期検査は是非必要なことで 岁る。

\section{2) mammography}

乳腺症は病理組織学的にも多彩な病像を呈专 るぶ， mammography の読影に関しても問題
Cystic Disease

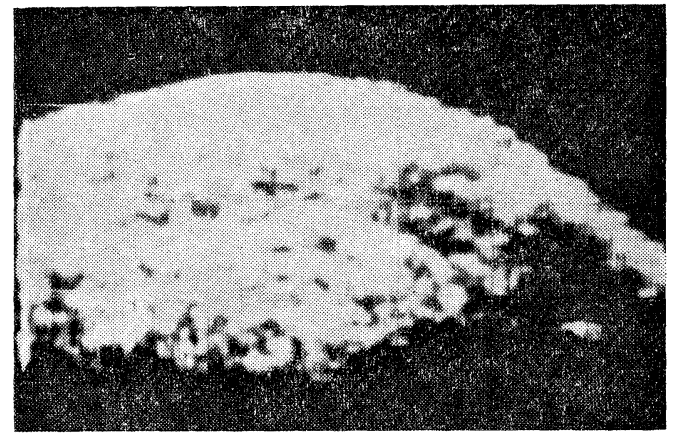

$0 \mathrm{~dB}$

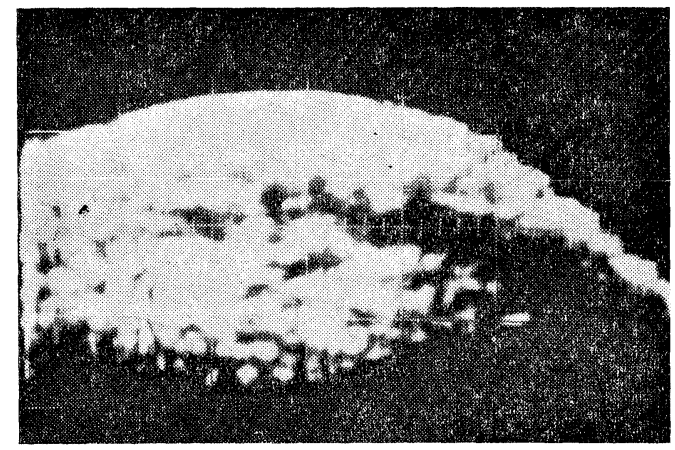

$3 \mathrm{~dB}$

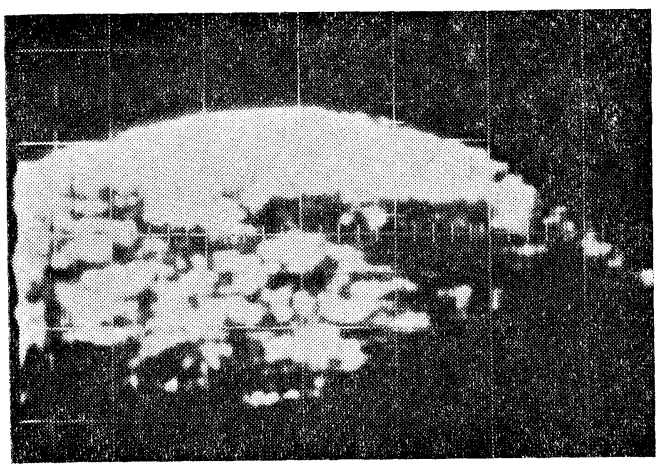

$6 \mathrm{~dB}$

は残されており診断困難な場合も多る。

乳腺症のX線像の特街以綿属様斑状㓌影末た はスリ硝子状除影でモヤモヤとした不鮮明な陰 影を示し,この中に梁柱棈造の増強が認められ る。また，時には大小不同の囊胞像を認めるこ

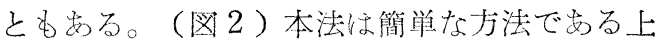




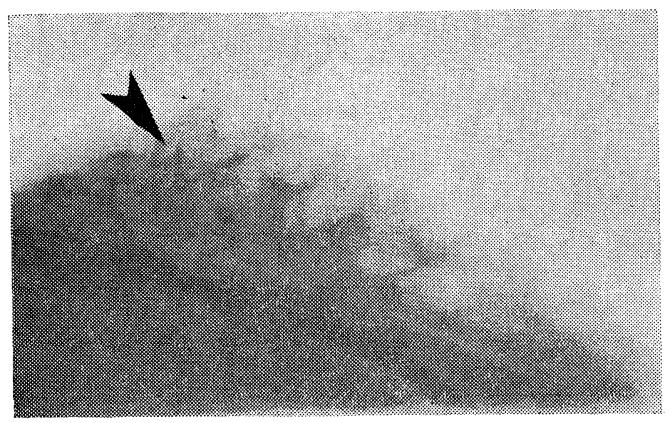

図 2 無数の小さな “綿首状”の陰影と 梁柱構造の増加がみられる

に最近では撮影条件, 方法が改善され私共はル チーンに行なっている。診断率は80-90\%が現 状である。

3) Xeroradiography, Thermography, Radioisotope

これらの診断法は今後の発展が期待される方 法である。

しかし，これらの補助的診断法にもそれぞれ の限界があるので，その方法の長所を生かし多 くの補助䛦断法を駆使して，綜合判定を下すよ らにすれば診断率をより向上させることが可能 である。

乳腺症の決定的診断法は生検法による組織学 的検査で女り，生検の場合には腫瘤とその周囲 の健常組織を含めて剔除すれば乳腺症の場合そ れだけで治療に代えることができ，悪性の場合 には癌細胞の散布の危険を防ぐことにるなる。

\section{2 病理学的所見}

乳腺症の病理学的分類は Foot \& Stewart の分類ないしこれに準じた分類を採用している 研究者が多い。本分類の特幑は腺上皮細胞の形 態ないしは配列の仕方预よび時期的推移に掞い て複雑な病理形態を分類したものである。これ によって部分像なる言葉も便利に使われ, 乳腺 症は增殖, 萎縮および化生の 3 病変を表わす複 雑な部分像の集まりであると表現できよう。

組織学的には次に述べる部分像が種々の割合 で混在しきわめて多彩である。
(1) 囊胞 Cystic change.

(2) 閉塞輸出管腺症 Blunt duct adenosis.

(3) 硬化性腺症 Sclerosing adenosis.

(4) アポクリン上皮化生 Apocrine metaplasia

(5) 輸出管乳頭腫症 Duct papillomatosis が主な変化である。このうち鑑別上問題となる のは輸出管乳頭腫症と乳頭上腺癌であり一乳腺 症の癌化一かなり慎重な組織学的判断を要する ことが多い。

\section{3 内分泌学的所見}

乳腺症患者のホルモン動態はエストロゲンは 增加し，17一ケトステロイドが隇少して拈り相 対的エストロゲン過剩状態 relative hyperestrogenism 扣よび分泌物吸収不全の刺激によ り必然的に輸出管系の増殖, 腺葉系の退縮掞よ び間質の增殖等の形態変化が起こるものと理解 される。当然こよのらな変化は両側性にから 澯漫性に出現し，ホルモン事情の変化に応じて ある程度可逆的であり固定化されたものが乳腺 症として取り报われるわ恀である。したがっ て, 理論的には性ホルモン環境を正常化するこ とによって是正しうるわけである。乳腺症に拉 けるホルモン療法の適応と限界もこの点にある といえよう。

\section{4 乳腺症の悪性化}

乳腺症と乳癌との関係については19世紀前半 より Sir Astley Cooper, Brodie, Reclus ら によって注目され，その後，内外の諸家により 問題点が㭘討されて来たが現在な扣定説がな い。しかし，疫学的研究や内分泌環境からの研 究を考えてみると乳腺症と乳癌とは密接な関係 がめることがらかがえる。一般に乳腺症の悪性 化の頻度は臨床的には10～30\%とするものが多 いが，病理学者の側からは0からせいぜい数\% にすぎないとするものが多い。既往の生検によ り乳腺症が確認された患者のなかからの癌化は 0 5.7\%で岁。（表 1 ） 
表 1 既往乳腺症患者（生検診断）からの 乳癌発生頻度

\begin{tabular}{|c|c|c|c|c|}
\hline 報 告 者 & 年 代 & $\begin{array}{l}\text { 調 查 } \\
\text { 例 数 }\end{array}$ & $\begin{array}{l}\text { 乳癌 } \\
\text { 例数 }\end{array}$ & $\%$ \\
\hline Johnson & 1924 & 442 & 1 & 0.22 \\
\hline Foote \& Stewart & 1945 & 1200 & 29 & 2.4 \\
\hline Patey \& Nurick & 1953 & 810 & 10 & 1.23 \\
\hline Haagensen & 1956 & 1544 & 9 & 0.6 \\
\hline Hendrick & 1957 & 452 & 4 & 0.88 \\
\hline Humphrey & 1962 & 369 & 21 & 5.7 \\
\hline 計 & $\ll$ & 4817 & 74 & 1.5) \\
\hline 藤田(がんセンター) & 1966 & 244 & 0 & 0 \\
\hline 山 崎(慶 大) & "I & 258 & 0 & 0 \\
\hline 間 島(東北大) & "I & 213 & 3 & 1.4 \\
\hline 烊 本(日 大) & 11 & 237 & 4 & 1.7 \\
\hline 林 （京 大） & 11 & 236 & 3 & 1.5 \\
\hline 計 & $\mathbb{R}$ & 1188 & 10 & $0.8)$ \\
\hline
\end{tabular}

外国文献例の合計では4817例中74例（1.5\%） である。本邦合計（第 3 回乳癌研究会報告）で は1188例中10例 $(0.8 \%)$ でやや低率である。 また，既往に乳腺症 (生検診断) と診断された 乳癌患者の初回組織所見をみる(表2), Duct papilloma および Duct papillomatosis が15例中11例 $(73 \%)$ と大部分を占めている。 その漂か Blunt duct adenosis が稀に悪性化 し, Apocrine epithelium もきわめて稀に悪 性化する。したがって, 臨床的には乳腺症患者 厳重に追跡すれば早期の乳癌患者を発見する ことができる。しかし, 乳腺症は增殖, 萎縮拉 よび化生の 3 病变をあらわす複雑な部分像の集 まりであるから部分像の中でる覀性化に対して 安定なものと，不安定なるのとに分類して考学
表 2 既往に乳腺症（生検診断）之診断された 乳癌患者の初回組織所見 （第 3 回乳癌研究会報告より）

\begin{tabular}{cc}
\hline ductal hyperplasia & \\
cell atypysm (軽度) & 1 case \\
border line & 1 case \\
duct papillomatosis & \\
severe grade & 1 case \\
border line & 6 cases \\
papilloma or duct papillomatosis & 1 case \\
papilloma & 2 cases \\
blunt duct adenosis & 1 case \\
blunt duct adenosis+ & \\
duct papillomatosis & 1 case \\
adenomatous solid pattern & \\
(cell atypsism) & 1 case \\
duration 1 年 1 カ月〜7年後までの期間で癌 \\
と診断されている。第 3 回乳癌研究会 (京都)
\end{tabular}

ね2ばならない。すなわち，いかなる変化が悪性 の可能性が高いかを知ることが乳腺症の将来を 推定末たは現在の治療方針決定の基礎にもな る。

\section{文献}

1) Foote, F. W. \& Stewart, F. W. Ann. Surg 121, 197, 1945.

2）乳腺症の超音波像と組織像 第8 回 日本超音波医 学会発表 1965.

3）現代外科学大系 29 , 中山書店, 1968. .

4）超音波診断入門 日本超音波医学会 1969.

5）渡辺弘。臨床外科 $24,179,1969$. 